\title{
Hydrologic factors controlling groundwater salinity in northwestern coastal zone, Egypt
}

\author{
Nahla A Morad ${ }^{1}$, M H Masoud $^{1,2, *}$ and S M Abdel Moghith ${ }^{1}$ \\ ${ }^{1}$ Hydrology Department, Desert Research Centre, Cairo, Egypt. \\ ${ }^{2}$ Water Research Centre, King Abdulaziz University, Jeddah, Saudi Arabia. \\ ${ }^{*}$ Corresponding author.e-mail: zakimilad@hotmail.com
}

The aim of this article is to assess the main factors influencing salinity of groundwater in the coastal area between El Dabaa and Sidi Barani, Egypt. The types and ages of the main aquifers in this area are the fractured limestone of Middle Miocene, the calcareous sandstone of Pliocene and the Oolitic Limestone of Pleistocene age. The aquifers in the area are recharged by seasonal rainfall of the order of $150 \mathrm{~mm} /$ year. The relationship of groundwater salinity against the absolute water level, the well drilling depth, and the ability of aquifer to recharge has been discussed in the present work. The ability of aquifer to locally recharge by direct rainfall is a measure of the vertical permeability due to lithological and structural factors that control groundwater salinity in the investigated aquifers. On the other hand, the fracturing system as well as the attitude of the surface water divide has a prime role in changing both the mode of occurrence and the salinity of groundwater in the area. Directly to the west of Matrouh, where the coastal plain is the narrowest, and east of Barrani, where the coastal plain is the widest, are good examples of this concept, where the water salinity attains its maximum and minimum limits respectively. Accordingly, well drilling in the Miocene aquifer, in the area between El Negila and Barrani to get groundwater of salinities less than $5000 \mathrm{mg} / \mathrm{l}$ is recommended in this area, at flow rate less than $10 \mathrm{~m}^{3} / \mathrm{hr} /$ well. In other words, one can expect that the brackish water is probably found where the surface water divide is far from the shore line, where the Wadi fill deposits dominate (Quaternary aquifer), acting as a possible water salinity by direct rainfall and runoff.

\section{Introduction}

During the last two decades, excessive well drilling operations tapping Middle Miocene fractured limestone have been executed searching for groundwater as a supplementary source for irrigation in summer and during drought events. From the comprehensive survey of groundwater conditions in the study area, it has been noticed that the groundwater widely ranges in salinity between 1000 and about $15000 \mathrm{mg} / \mathrm{l}$. This great variation in salinity is mainly attributed to the dominant hydrologic conditions controlling the groundwater occurrence and recharge.

The present work deals principally with the assessment of the relationship between groundwater salinity and the absolute water level, the drilled depth below sea level, the storm events and possibility of runoff, the attitude of water divide, and the rate of pumping causing sea water intrusion.

The area is, occasionally, subjected to heavy storms $(10-20 \mathrm{~mm} /$ storm) causing flash floods in a number of drainage lines (over 200 Wadis) dissecting the Middle Miocene plateau in the south

Keywords. Brackish groundwater; aquifer; northwestern coast; Egypt. 
and running towards the sea in the north. The study is based on the data of 150 water wells, distributed among the aquifers all over the area. Data collection started in February 2010 and continued for more than 2 years (June 2012). The area is suffering seriously from drought and water scarcity all the year round, particularly in summer months. People in this area are looking urgently for groundwater for cultivation and range vegetation, but the sources are limited and the quality is poor. The present work may help the inhabitants to find resources of less salinity and more productivity.

\section{Phyisography}

The study area covers an area of about $26,000 \mathrm{~km}^{2}$, extending from El Dabaa in the east to Sidi Barrani in the west (figure 1). It is bound by the Mediterranean Sea in the north and Marmarica Plateau in the south. The altitude of the study area ranges between zero level (Mediterranean Sea) and about $200 \mathrm{~m}$ above mean sea level (water divide). It slopes gently to the north, i.e., towards the Mediterranean Sea.

According to Zaki (2000), from the Digital Elevation Model (DEM) of the study area (figure 1), it is noticed that the distance between the shore line and the water divide varies widely from $25 \mathrm{~km}$ in the west of Matrouh (minimum width) to $80 \mathrm{~km}$ in Mersa El Asi (maximum width).
This reflects that the Wadis dissecting the plateau are represented in the area between Mersa El Asi and Sidi Barrani, where the water divide is far away from the shore line. Between Matrouh and Ras El Hekma, the water divide is very close to the shore line and Wadis are almost short and shallow.

The climate of the northwestern coastal zone is characterized by long rainless summers and short rainy winters (October to April). In general, the region is related to the Arid Mediterranean climate. The data collected from the Egyptian Meteorological Authority (EMA 1950-2000) show that the maximum temperature was recorded in August $\left(30.4^{\circ} \mathrm{C}\right)$ while the minimum temperature was $\left(8.2^{\circ} \mathrm{C}\right)$ in January. The average monthly evaporation per day ranges between $5.5 \mathrm{~mm}$ /day in January and $8.0 \mathrm{~mm} /$ day in April. The average annual rainfall ranges between $130 \mathrm{~mm}$ in El Dabaa station and $153 \mathrm{~mm}$ in Sidi Barrani station. The maximum rainfall in one day recorded in northwestern coastal zone was $63.8 \mathrm{~mm}$ (Matruh station at 13 December 1977). The number of rainy days ranges between 30 and 60 days in the area of study.

\section{Groundwater occurrence and mechanism of recharge}

The groundwater in the study area occurs in four rock types (aquifers) of Tertiary and Quaternary ages (figure 2). The Quaternary aquifers are dominated along the coastal plain and the dissecting
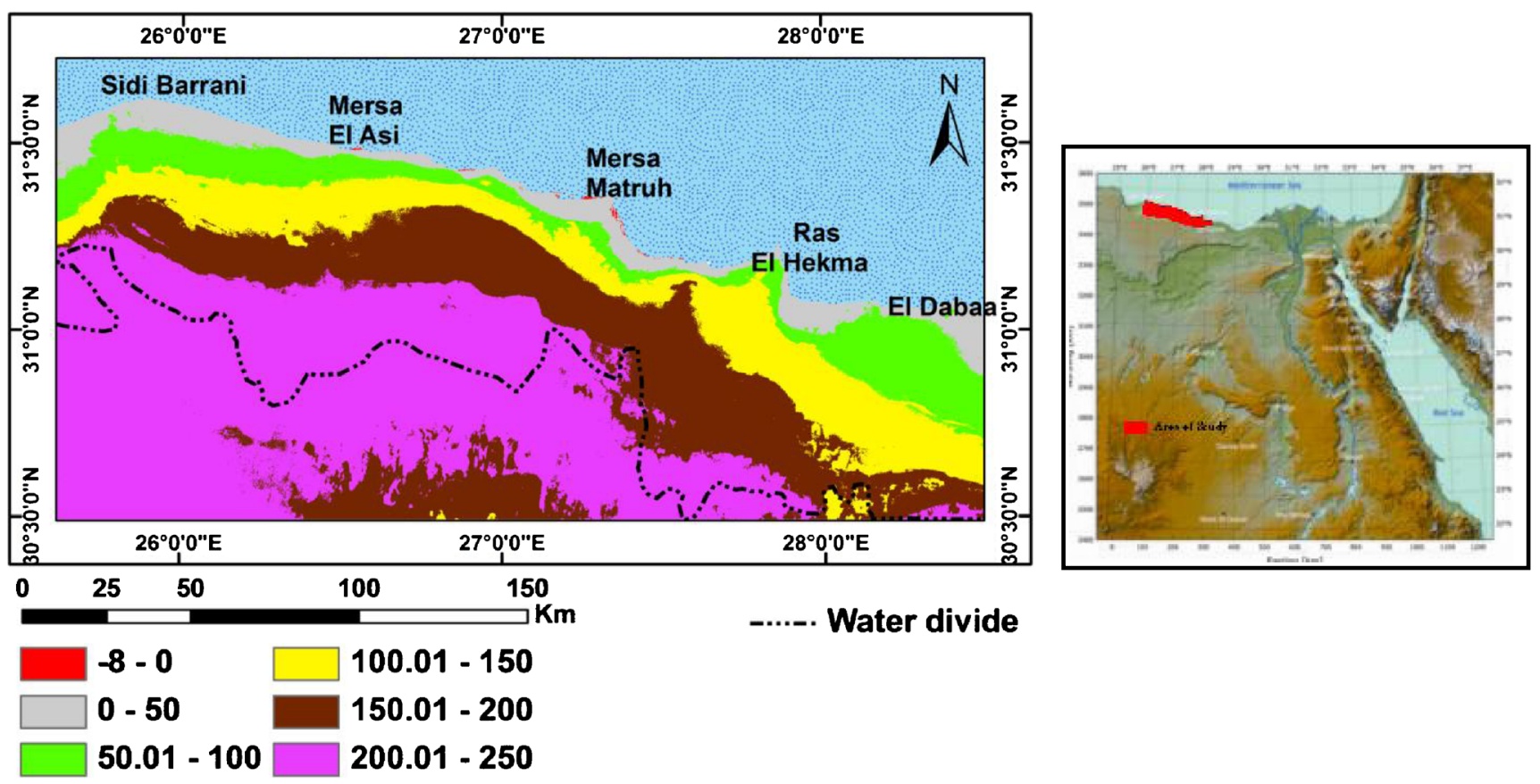

Figure 1. Location map and Digital Elevation Model (DEM) of the study area. 


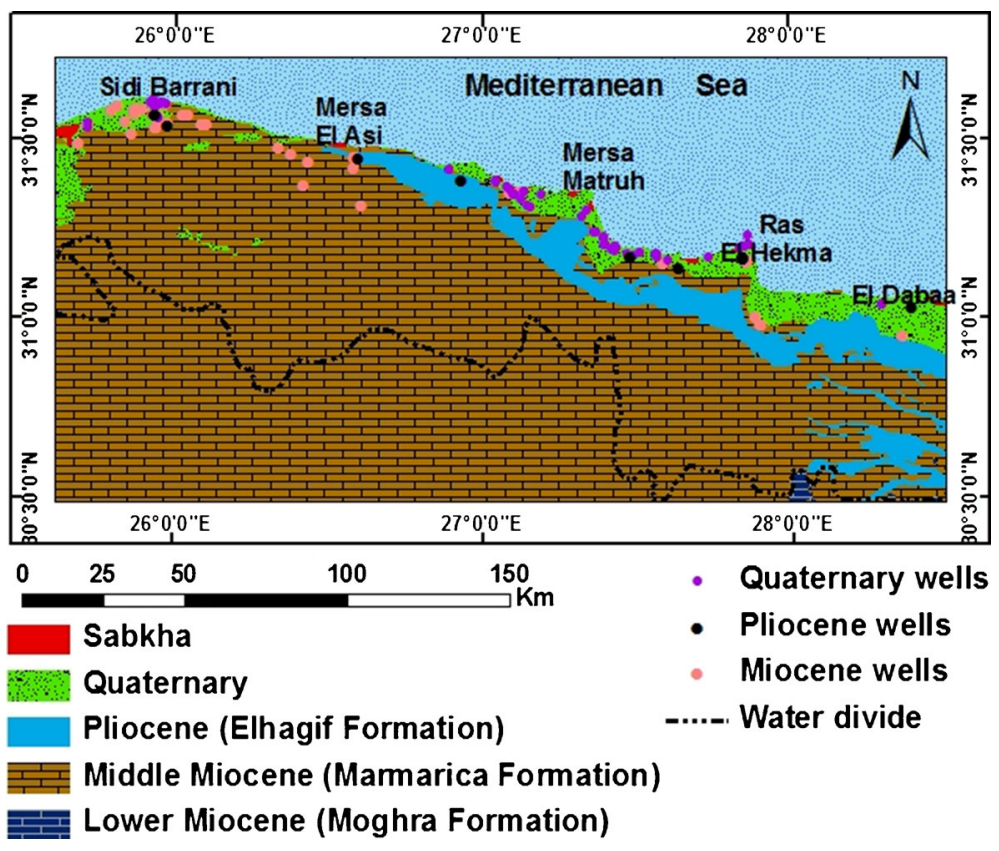

Figure 2. The main geological units of the North West Coastal Zone (CONOCO 1989), showing the edge of Miocene plateau $(+200 \mathrm{~m})$ and the location of wells for each aquifer.

Wadis, having an area of about $1870 \mathrm{~km}^{2}(7 \%$ of the total area). The Pliocene rocks are either exposed on surface or underlie the Quaternary sediments, while the Miocene rocks form the surface beds of the southern plateau.

The Quaternary carbonate aquifer is directly connected to the Mediterranean Sea, which affects the groundwater salinity considerably. It is reported in the study area by two main facies; namely the Oolitic Limestone of late Pleistocene age and the Alluvium deposits of Holocene age, which are located mostly in the Wadis running perpendicular to the shore line. Due to the overpumping from the wells tapping the Quaternary aquifer; sea water intrusion may occur causing an increased water salinity.

The Pliocene aquifer underlies the Pleistocene aquifer and overlies the Miocene aquifer. The exposed deposits cover an area of about 2300 $\mathrm{km}^{2}$ (9\% of the total area). The facies of the Pliocene is mainly calcareous sandstone of porous nature.

The Miocene aquifer has an area about 22,250 $\mathrm{km}^{2}$ ( $84 \%$ of the total area), representing one of the main aquifers in the study area occupying the so called Marmarica Plateau. The groundwater of this aquifer occurs in two main forms: Perched groundwater, where the water level is above mean sea level and main water table where the water is free or in semi-confined conditions. The facies of this aquifer is fractured limestone and dolomite. Most of the rainfall on the southern plateau runs on the surface causing water runoff, while it partially recharges the perched water table close to the ground surface.

About 130 wells were selected for the present study; these wells were drilled in three different aquifers. Tables 1,2 and 3 show the basic data of wells, while figure 2 shows the distribution of these wells in the study area. Among the investigated aquifer, where 64 drilled wells tap the Quaternary aquifer, while 11 and 55 wells tap the Pliocene and Miocene aquifers, respectively. The percentage of wells for the three aquifer types are $50 \%, 8 \%$, and $42 \%$ for the Quaternary, Pliocene and Miocene, respectively.

From the literature (Saleh 2000), the average permeability values of the investigated aquifers in the study area vary widely from one aquifer to another and from locality to locality. The permeability $(\mathrm{K})$ for the alluvium (Wadi deposits) ranges between $8.2 \mathrm{~m} /$ day in Sidi Barrani and $25.1 \mathrm{~m} /$ day west of Matrouh. The Oolitic limestone (Pleistocene age) shows $\mathrm{K}$ values ranging from $1.2 \mathrm{~m} /$ day near Ras El Hekma to $22.6 \mathrm{~m} /$ day near Matrouh. The Middle Miocene rocks (fractured limestone) attain the lowest permeability value $(0.35 \mathrm{~m} /$ day $)$ among all aquifers, which is quite expected due to the fracturing nature of the building material.

The measured depth to water table from groundwater surface varies between 6 and $35 \mathrm{~m}$ for the Quaternary and between 30 and $90 \mathrm{~m}$ for the Pliocene aquifer and between 25 and $98 \mathrm{~m}$ for the Miocene aquifer. The depth to water table is directly proportional to the ground elevation at the measuring points. 
Table 1. Basic data of the Quaternary wells.

\begin{tabular}{|c|c|c|c|c|c|c|c|}
\hline \multirow[b]{2}{*}{ No. } & \multicolumn{2}{|c|}{ Location } & \multirow{2}{*}{$\begin{array}{c}\text { Salinity } \\
(\mathrm{mg} / \mathrm{l})\end{array}$} & \multirow{2}{*}{$\begin{array}{l}\text { Drilled } \\
\text { depth } \\
(\mathrm{m})\end{array}$} & \multirow{2}{*}{$\begin{array}{l}\text { Depth to } \\
\text { water } \\
(\mathrm{m})\end{array}$} & \multirow{2}{*}{$\begin{array}{l}\text { Elevation } \\
\qquad(\mathrm{m}) \\
\text { a.m.s.l. }\end{array}$} & \multirow{2}{*}{$\begin{array}{c}\text { Water } \\
\text { table } \\
(\mathrm{m})\end{array}$} \\
\hline & Longitude & $\overline{\text { Latitude }}$ & & & & & \\
\hline 1 & 25.965 & 31.604 & 9837 & 24 & 16 & 19 & 3 \\
\hline 2 & 25.919 & 31.608 & 7450 & 40 & 30 & 28 & -2 \\
\hline 3 & 25.913 & 31.608 & 7392 & 37 & 30 & 29 & -1 \\
\hline 4 & 25.921 & 31.603 & 1434 & 40 & 31 & 29 & -2 \\
\hline 5 & 25.921 & 31.603 & 1363 & 42 & 31 & 29 & -2 \\
\hline 6 & 25.929 & 31.604 & 4435 & 47 & 38 & 27 & -11 \\
\hline 7 & 25.931 & 31.603 & 7936 & 50 & 38 & 27 & -11 \\
\hline 8 & 25.946 & 31.602 & 7168 & 35 & 24 & 25 & 1 \\
\hline 9 & 25.947 & 31.607 & 8576 & 46 & 30 & 22 & -8 \\
\hline 10 & 25.931 & 31.594 & 8256 & 52 & 34 & 33 & -1 \\
\hline 11 & 25.929 & 31.591 & 7360 & 49 & 37 & 39 & 2 \\
\hline 12 & 25.937 & 31.561 & 7168 & 48 & 36 & 45 & 9 \\
\hline 13 & 25.922 & 31.613 & 12032 & 30 & 22 & 23 & 1 \\
\hline 14 & 25.921 & 31.612 & 6592 & 30 & 23 & 24 & 1 \\
\hline 15 & 25.711 & 31.548 & 5517 & 47 & 38 & 42 & 4 \\
\hline 16 & 25.711 & 31.536 & 5075 & 43 & 35 & 39 & 4 \\
\hline 17 & 28.293 & 31.041 & 700 & 60 & 32 & 39 & 7 \\
\hline 18 & 28.292 & 31.042 & 3328 & 60 & 30 & 40 & 10 \\
\hline 19 & 28.292 & 31.042 & 1792 & 60 & 27 & 40 & 13 \\
\hline 20 & 25.923 & 31.603 & 2240 & 40 & 30 & 29 & -1 \\
\hline 21 & 27.861 & 31.237 & 7040 & 31 & 25 & 26 & 1 \\
\hline 22 & 27.863 & 31.209 & 11520 & 20 & 16 & 8 & -8 \\
\hline 23 & 27.847 & 31.207 & 4672 & 12 & 10 & 12 & 2 \\
\hline 24 & 27.847 & 31.207 & 3200 & 12 & 10 & 12 & 2 \\
\hline 25 & 27.847 & 31.206 & 8960 & 12 & 10 & 13 & 3 \\
\hline 26 & 27.844 & 31.206 & 6720 & 12 & 10 & 12 & 2 \\
\hline 27 & 27.842 & 31.206 & 9600 & 13 & 11 & 13 & 2 \\
\hline 28 & 27.834 & 31.203 & 1306 & 18 & 16 & 17 & 1 \\
\hline 29 & 27.733 & 31.178 & 3699 & 21 & 18 & 19 & 1 \\
\hline 30 & 27.323 & 31.293 & 2368 & 30 & 28 & 31 & 3 \\
\hline 31 & 27.339 & 31.309 & 9600 & 12 & 10 & 20 & 10 \\
\hline 32 & 27.367 & 31.246 & 7552 & 25 & 16 & 19 & 3 \\
\hline 33 & 27.361 & 31.249 & 5120 & 16 & 13 & 14 & 1 \\
\hline 34 & 27.361 & 31.249 & 4480 & 21 & 11 & 22 & 11 \\
\hline 35 & 27.392 & 31.233 & 4480 & 17 & 11 & 13 & 2 \\
\hline 36 & 27.392 & 31.232 & 2048 & 15 & 11 & 13 & 2 \\
\hline 37 & 27.426 & 31.194 & 15360 & 30 & 24 & 27 & 3 \\
\hline 38 & 27.486 & 31.183 & 10880 & 32 & 23 & 23 & 0 \\
\hline 39 & 27.469 & 31.186 & 16640 & 33 & 22 & 23 & 1 \\
\hline 40 & 27.599 & 31.169 & 13440 & 50 & 28 & 39 & 11 \\
\hline 41 & 27.559 & 31.184 & 8960 & 45 & 27 & 20 & -7 \\
\hline 42 & 27.564 & 31.187 & 11840 & 23 & 22 & 18 & -4 \\
\hline 43 & 27.564 & 31.178 & 12160 & 36 & 24 & 30 & 6 \\
\hline 44 & 27.509 & 31.192 & 928 & 21 & 9 & 13 & 4 \\
\hline 45 & 27.431 & 31.203 & 7872 & 18 & 12 & 12 & 0 \\
\hline 46 & 27.428 & 31.204 & 3840 & 18 & 8 & 11 & 3 \\
\hline 47 & 27.428 & 31.208 & 6016 & 12 & 6 & 7 & 1 \\
\hline 48 & 27.418 & 31.198 & 3840 & 25 & 14 & 18 & 4 \\
\hline 49 & 27.428 & 31.204 & 1618 & 17 & 10.4 & 9 & -1.4 \\
\hline 50 & 27.398 & 31.214 & 10560 & 22 & 14.4 & 17 & 2.6 \\
\hline 51 & 27.393 & 31.213 & 16512 & 27 & 17 & 19 & 2 \\
\hline 52 & 27.188 & 31.354 & 7923 & 10 & 6.94 & 9 & 2.06 \\
\hline 53 & 27.043 & 31.389 & 3776 & 10 & 7 & 24 & 17 \\
\hline 54 & 27.043 & 31.392 & 2560 & 5 & 4 & 3 & -1 \\
\hline
\end{tabular}


Table 1. (Continued.)

\begin{tabular}{|c|c|c|c|c|c|c|c|}
\hline \multirow[b]{2}{*}{ No. } & \multicolumn{2}{|c|}{ Location } & \multirow{2}{*}{$\begin{array}{c}\text { Salinity } \\
(\mathrm{mg} / \mathrm{l})\end{array}$} & \multirow{2}{*}{$\begin{array}{c}\text { Drilled } \\
\text { depth } \\
(\mathrm{m})\end{array}$} & \multirow{2}{*}{$\begin{array}{c}\text { Depth to } \\
\text { water } \\
(\mathrm{m})\end{array}$} & \multirow{2}{*}{$\begin{array}{c}\text { Elevation } \\
\qquad(\mathrm{m}) \\
\text { a.m.s.l. }\end{array}$} & \multirow{2}{*}{$\begin{array}{l}\text { Watel } \\
\text { table } \\
(\mathrm{m})\end{array}$} \\
\hline & Longitude & Latitude & & & & & \\
\hline 55 & 27.075 & 31.376 & 2803 & 7 & 6 & 7 & 1 \\
\hline 56 & 27.086 & 31.368 & 6400 & 20 & 12 & 18 & 6 \\
\hline 57 & 27.101 & 31.354 & 5888 & 26 & 20 & 25 & 5 \\
\hline 58 & 27.098 & 31.353 & 5184 & 32 & 23 & 31 & 8 \\
\hline 59 & 26.889 & 31.423 & 1523 & 19 & 10 & 9 & -1 \\
\hline 60 & 27.133 & 31.362 & 5562 & 7.3 & 6.5 & 8 & 1.5 \\
\hline 61 & 27.132 & 31.362 & 7334 & 8.66 & 7.86 & 9 & 1.14 \\
\hline 62 & 27.124 & 31.338 & 3200 & 13 & 10.7 & 26 & 15.3 \\
\hline 63 & 27.143 & 31.321 & 3136 & 10 & 8.4 & 43 & 34.6 \\
\hline 64 & 27.156 & 31.318 & 5312 & 42 & 16.7 & 45 & 28.3 \\
\hline
\end{tabular}

From the data of both permeability and of depth to water table from ground surface, one can conclude that the higher the permeability value and the lower the depth to water surface, the higher the potentiality or ability of aquifer recharge.

In other words, the ability of aquifer recharge by local rainfall especially for the exposed part of the rocks indicates that:

- The alluvium aquifer (Wadi deposits) has the highest ability of recharge.

- The Pleistocene Oolitic limestone has a medium ability of recharge.

- The Miocene aquifer has the lowest ability of recharge by local rainfall.

In conclusion, the groundwater in the study area occurs in four forms as follows:

1) Free water table in the Oolitic limestone and alluvium aquifers along the shore line, directly recharged from the seasonal rainfall.

2) Free water table of the Pliocene calcareous sandstone, where the rocks are exposed on the surface.

3) Perched water table within the Miocene rocks, which is indirectly recharged through the over lying fractured rocks.

4) Free to semi-confined aquifer of the Miocene fractured rocks, indirectly recharged through the natural groundwater movement from south to north.

One expects that such conditions considerably influence the groundwater salinity for each aquifer if the other hydrologic factors can be excluded.

\subsection{Groundwater salinity}

In general, the ground water salinity in the study area ranges between less than $1000 \mathrm{mg} / \mathrm{l}$ and about $15000 \mathrm{mg} / \mathrm{l}$. Most of the wells $(38.2 \%)$ have a salinity range from 5000 to $10000 \mathrm{mg} / \mathrm{l}$, while $27.6 \%$ of them have a range of 1000 to $15000 \mathrm{mg} / \mathrm{l}$. Figure 3 shows the frequency distribution of the total salinity among the investigated aquifers. From this table the following can be noticed:

1) In the Quaternary aquifer, in about $46 \%$ of the total wells groundwater salinity ranges from 5000 to $10000 \mathrm{mg} / \mathrm{l}$, while in $39 \%$ of the total wells groundwater salinity is $<5000 \mathrm{mg} / \mathrm{l}$.

2) In the Miocene aquifer, in more than half of the total wells $(56 \%)$ groundwater salinity ranges from 5000 to $10000 \mathrm{mg} / \mathrm{l}$, while in $45.3 \%$ of total wells, groundwater salinity is $<50,000 \mathrm{mg} / \mathrm{l}$.

3) All the selected wells in the Plioceneaquifer $(100 \%)$ have groundwater salinity $<5000 \mathrm{mg} / \mathrm{l}$.

4) In general, the ground water salinity of the Pleistocene aquifer is mainly attributed to the sea water intrusion because of two reasons:

- Overpumping of the wells tapping the Oolitic limestone aquifer.

- The Oolitic limestone aquifer is directly connected to the sea from the lithological point of view.

The iso-salinity contour maps for both the Quaternary and Miocene aquifers (figures 4 and 5) show the following:

- In the Quaternary aquifer, the minimum salinity (1000-5000 mg/l) is located in two specific areas (between Mersa El Asi and Mersa Matrouh and East El Dabaa), while in the other two areas (between Mersa Matrouh and Sidi Barani and between Mersa Matrouh and El Dabaa), groundwater salinity ranges from 5000 to 10000 $\mathrm{mg} / \mathrm{l}$. The high groundwater salinity $(>10000$ $\mathrm{mg} / \mathrm{l})$ is located as a small patch between Mersa Matrouh and Ras El Hekma.

- In the Miocene aquifer, the area of low groundwater salinity $(<5000 \mathrm{mg} / \mathrm{l})$ is located in the area to the west of Mersa El Asi, between El Negila and Sidi Barrani. The maximum salinity is located in the area of El Daba (>10000 mg/l). 
Table 2. Basic data of the Miocene wells.

\begin{tabular}{|c|c|c|c|c|c|c|c|}
\hline \multirow[b]{2}{*}{ No. } & \multicolumn{2}{|c|}{ Location } & \multirow{2}{*}{$\begin{array}{c}\text { Salinity } \\
(\mathrm{mg} / \mathrm{l})\end{array}$} & \multirow{2}{*}{$\begin{array}{l}\text { Drilled } \\
\text { depth } \\
\text { (m) }\end{array}$} & \multirow{2}{*}{$\begin{array}{l}\text { Depth to } \\
\text { water } \\
(\mathrm{m})\end{array}$} & \multirow{2}{*}{$\begin{array}{l}\text { Elevation } \\
\qquad(\mathrm{m}) \\
\text { a.m.s.l. }\end{array}$} & \multirow{2}{*}{$\begin{array}{c}\text { Water } \\
\text { table } \\
(\mathrm{m})\end{array}$} \\
\hline & Longitude & $\overline{\text { Latitude }}$ & & & & & \\
\hline 1 & 26.020 & 31.571 & 4781 & 63 & 48 & 29 & -19 \\
\hline 2 & 26.034 & 31.570 & 7834 & 38 & 31 & 31 & 0 \\
\hline 3 & 25.972 & 31.550 & 4128 & 79 & 45 & 43 & -2 \\
\hline 4 & 26.372 & 31.465 & 4966 & 80 & 57 & 59 & 2 \\
\hline 5 & 26.429 & 31.442 & 5434 & 98 & 73 & 67 & -6 \\
\hline 6 & 26.417 & 31.379 & 4435 & 115 & 95 & 106 & 11 \\
\hline 7 & 26.332 & 31.483 & 5024 & 80 & 62 & 53 & -9 \\
\hline 8 & 26.096 & 31.546 & 4723 & 50 & 38 & 37 & -1 \\
\hline 9 & 26.091 & 31.548 & 4563 & 53 & 41 & 37 & -4 \\
\hline 10 & 26.094 & 31.546 & 4730 & 52 & 38 & 36 & -2 \\
\hline 11 & 26.080 & 31.544 & 4493 & 55 & 40 & 39 & -1 \\
\hline 12 & 25.933 & 31.538 & 6912 & 66 & 50 & 52 & 2 \\
\hline 13 & 26.081 & 31.546 & 4595 & 60 & 40 & 37 & -3 \\
\hline 14 & 27.087 & 31.356 & 5933 & 40 & 25 & 29 & 4 \\
\hline 15 & 27.086 & 31.361 & 6560 & 40 & 23 & 21 & -2 \\
\hline 16 & 27.116 & 31.360 & 8640 & 24 & 11 & 12 & 1 \\
\hline 17 & 26.593 & 31.452 & 6336 & 90 & 71 & 75 & 4 \\
\hline 18 & 26.580 & 31.424 & 5568 & 115 & 94 & 92 & -2 \\
\hline 19 & 25.967 & 31.604 & 10240 & 24 & 16 & 16 & 0 \\
\hline 20 & 25.925 & 31.574 & 10432 & 55 & 45 & 47 & 2 \\
\hline 21 & 25.925 & 31.573 & 3392 & 80 & 44 & 47 & 3 \\
\hline 22 & 25.971 & 31.542 & 1574 & 70 & 41 & 43 & 2 \\
\hline 23 & 25.968 & 31.542 & 1280 & 71 & 41 & 43 & 2 \\
\hline 24 & 26.036 & 31.571 & 4659 & 38 & 30.65 & 31 & 0.35 \\
\hline 25 & 26.021 & 31.571 & 2794 & 63 & 31 & 31 & 0 \\
\hline 26 & 25.682 & 31.491 & 2688 & 61 & 30 & 31 & 1 \\
\hline 27 & 26.604 & 31.320 & 5670 & - & - & 149 & \\
\hline 28 & 26.578 & 31.457 & 5357 & 85 & 69 & 69 & 0 \\
\hline 29 & 25.938 & 31.573 & 7936 & 55 & 42 & 40 & -2 \\
\hline 30 & 25.937 & 31.561 & 7808 & 57 & 48 & 45 & -3 \\
\hline 31 & 25.930 & 31.537 & 7296 & 61 & 51 & 49 & -2 \\
\hline 32 & 25.860 & 31.587 & 5069 & 56 & 44 & 42 & -2 \\
\hline 33 & 25.865 & 31.587 & 5786 & 60 & 45 & 42 & -3 \\
\hline 34 & 25.866 & 31.583 & 6784 & 56 & 44 & 43 & -1 \\
\hline 35 & 25.862 & 31.581 & 7936 & 67 & 43 & 44 & 1 \\
\hline 36 & 25.807 & 31.594 & 8768 & 55 & 44 & 38 & -6 \\
\hline 37 & 25.787 & 31.581 & 6080 & 52 & 42 & 45 & 3 \\
\hline 38 & 25.709 & 31.543 & 7680 & 54 & 45 & 44 & -1 \\
\hline 39 & 25.889 & 31.590 & 5754 & 54 & 47 & 46 & -1 \\
\hline 40 & 25.862 & 31.573 & 9280 & 50 & 43 & 45 & 2 \\
\hline 41 & 25.833 & 31.554 & 9728 & 54 & 42 & 42 & 0 \\
\hline 42 & 25.855 & 31.518 & 5267 & 82 & 68 & 67 & -1 \\
\hline 43 & 28.358 & 30.954 & 15360 & 80 & 72 & 68 & -4 \\
\hline 44 & 27.857 & 31.165 & 4480 & 116 & 98 & 73 & -25 \\
\hline 45 & 27.847 & 31.169 & 8960 & 114 & 88 & 84 & -4 \\
\hline 46 & 27.584 & 31.161 & 6624 & 64 & 55 & 66 & 11 \\
\hline 47 & 27.855 & 31.162 & 4608 & 115 & 87 & 83 & -4 \\
\hline 48 & 27.901 & 30.985 & 9984 & 110 & 85 & 76 & -9 \\
\hline 49 & 27.899 & 30.988 & 12160 & 90 & 75 & 67 & -8 \\
\hline 50 & 27.882 & 31.008 & 4864 & 90 & 75 & 65 & -10 \\
\hline
\end{tabular}


Table 3. Basic data of the Pliocene wells.

\begin{tabular}{|c|c|c|c|c|c|c|c|}
\hline \multirow[b]{2}{*}{ No. } & \multicolumn{2}{|c|}{ Location } & \multirow{2}{*}{$\begin{array}{c}\text { Salinity } \\
(\mathrm{mg} / \mathrm{l})\end{array}$} & \multirow{2}{*}{$\begin{array}{l}\text { Drilled } \\
\text { Depth } \\
(\mathrm{m})\end{array}$} & \multirow{2}{*}{$\begin{array}{l}\text { Depth to } \\
\text { Water } \\
(\mathrm{m})\end{array}$} & \multirow{2}{*}{$\begin{array}{c}\text { Elevation } \\
\qquad(\mathrm{m}) \\
\text { a.m.s.l. }\end{array}$} & \multirow{2}{*}{$\begin{array}{l}\text { Water } \\
\text { Table } \\
(\mathrm{m})\end{array}$} \\
\hline & Longitude & Latitude & & & & & \\
\hline 1 & 26.931 & 31.392 & 832 & 120 & 58 & 95 & 37 \\
\hline 2 & 26.592 & 31.451 & & 100 & 90 & 73 & -17 \\
\hline 3 & 25.928 & 31.573 & 3379 & 62 & 51 & 43 & -8 \\
\hline 4 & 25.928 & 31.573 & 768 & 67 & 47 & 43 & -4 \\
\hline 5 & 25.969 & 31.541 & 1050 & 70 & 47 & 42 & -5 \\
\hline 6 & 25.930 & 31.573 & 1126 & 65 & 50 & 43 & -7 \\
\hline 7 & 27.844 & 31.173 & 3085 & 100 & 75 & 73 & -2 \\
\hline 8 & 27.843 & 31.173 & 704 & 100 & 75 & 74 & -1 \\
\hline 9 & 28.392 & 31.029 & 3053 & 65 & 42 & 39 & -3 \\
\hline 10 & 27.478 & 31.175 & 2816 & 51 & 31 & 40 & 9 \\
\hline 11 & 27.636 & 31.145 & 2086 & 72 & 58 & 98 & 40 \\
\hline
\end{tabular}

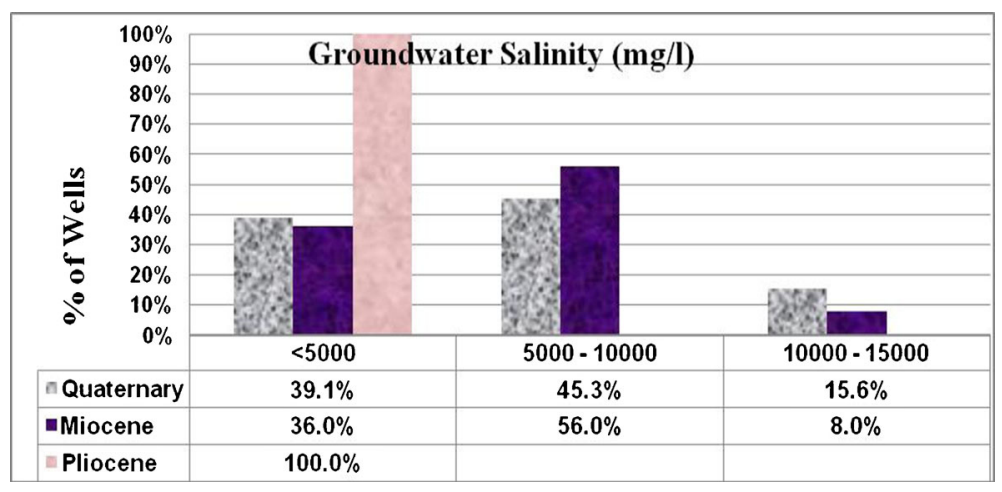

Figure 3. Frequency distribution of the groundwater salinity among the investigated aquifers.

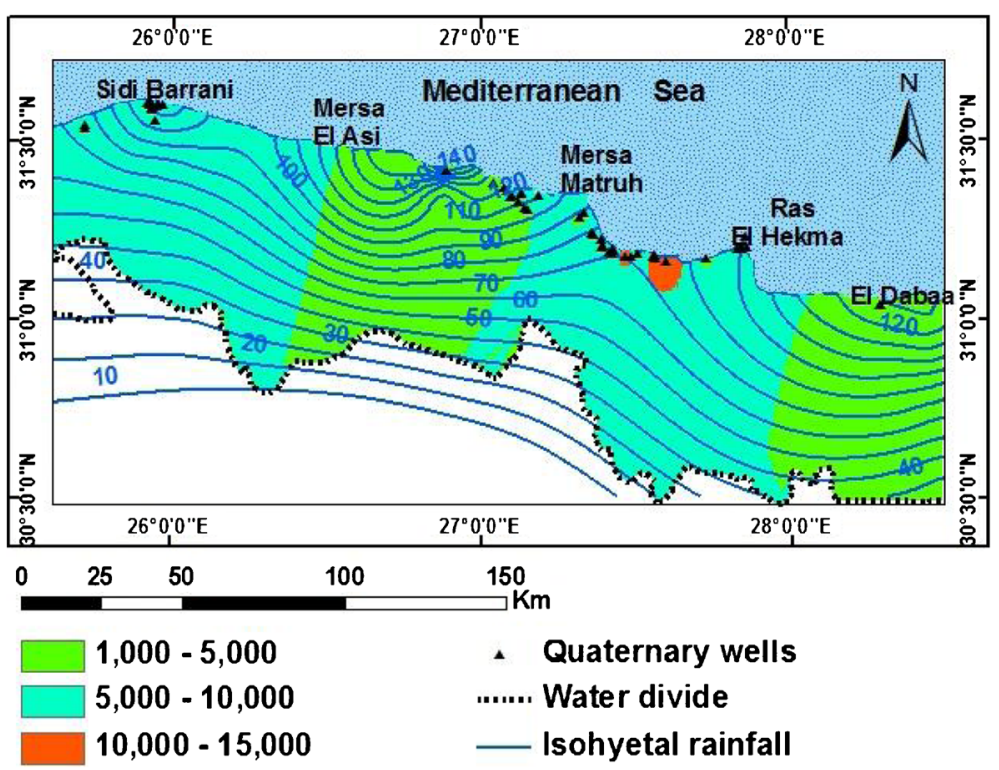

Figure 4. Iso-salinity contour map and relation between the rainfall and TDS of the Quaternary aquifer. 


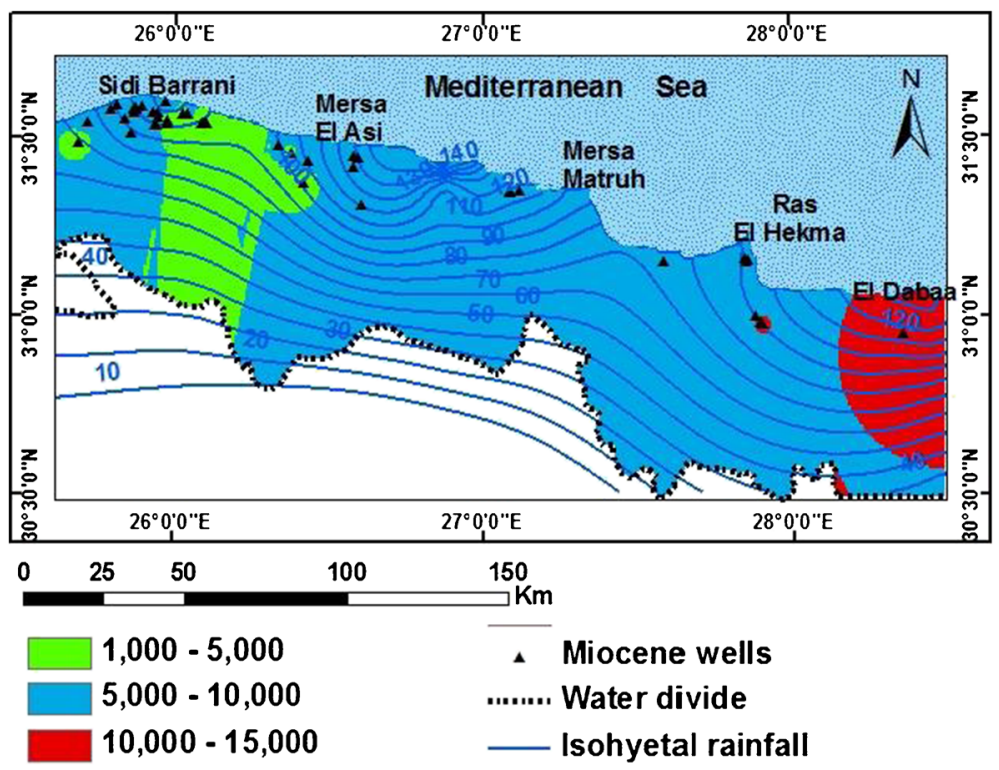

Figure 5. Iso-salinity contour map and relation between the rainfall and TDS of the Miocene aquifer.

In the present work, the main factors affecting the groundwater salinity have been assessed separately, as follows:

\subsubsection{Rainfall-salinity relationship}

From figures 4 and 5, the following can be concluded:

- In the Quaternary aquifer, the area having groundwater salinity $<5000 \mathrm{mg} / \mathrm{l}$ is located between Mersa El Asi and Mesra Matrouh. From the Isohyetal map, this area has the maximum recorded rainfall $(>120 \mathrm{~mm} /$ year $)$. This indicates that the groundwater salinity and rainfall in the Quaternary aquifer are inversely proportional; i.e., the area of high rainfall rate has less groundwater salinity. This relation indicates that the Quaternary aquifer is directly recharged from the rainfall.

- In the Miocene aquifer, the area of low groundwater salinity $(<5000 \mathrm{mg} / \mathrm{l})$ is located between Sidi Barrani and west of Mersa El Asi, while the area of high rainfall is located in the center of the study area (between Mersa El Asi and Mersa Matrouh) having groundwater salinity range from $5000-10000 \mathrm{mg} / \mathrm{l}$. This indicates that the Miocene aquifer is indirectly recharged from the local rainfall.

\subsubsection{Water level-salinity relationship}

From figures 6,7 and 8 , the following can be noticed:

- A majority of the wells in the study area have a water level range between -5 and +5 .
- In the Quaternary aquifer, in the area between Sidi Barrani and West Matruh, the water level decreases in the north direction towards the sea; i.e., the movement of the groundwater is from south to north.

- In the Quaternary aquifer, a majority of the wells $(75 \%)$ have a positive water level (above mean sea level). This positive aquifer emphasises the impact of direct recharge upon the exposed Quaternary deposits.

- The water level in the Miocene aquifer ranges from +10 to $-14 \mathrm{~m}$. The water level decreases in the north direction.

- In the Miocene aquifer, a majority of the wells (about $67 \%$ of the total wells) have water level below seawater level (negative), because of the lack of direct recharge either from the rainfall or from the surface runoff. In other words, there is a direct relation between the water level and the possibility of direct recharge.

- The number of wells is very few in the Pliocene aquifer (11 wells), so it cannot be studied thoroughly. The water levels in these wells vary between -17 and $+40 \mathrm{~m}$.

Although there is a proportional impact of water level upon water salinity, figures 9 and 10 show that the relationship between both variables is illdefined in both Quaternary and Miocene aquifers. This feature may reflect that the water salinity in the area is strongly affected by other hydrological factors rather than the absolute water level.

\subsubsection{Drilled depth-salinity relationship}

The relationship between the groundwater salinity and the drilled depth below the sea level is 


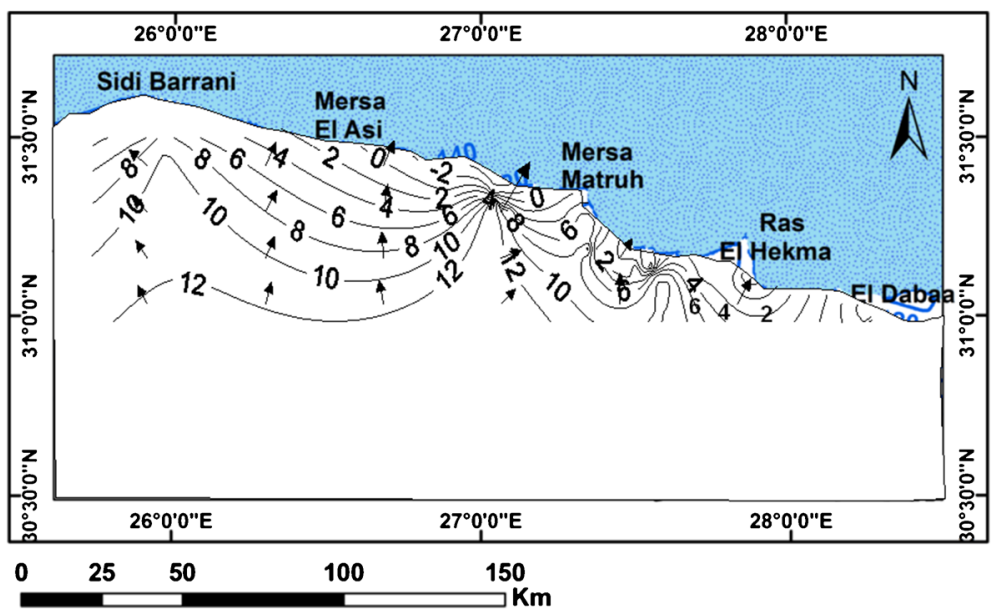

Figure 6. Water table map in the Quaternary aquifer.

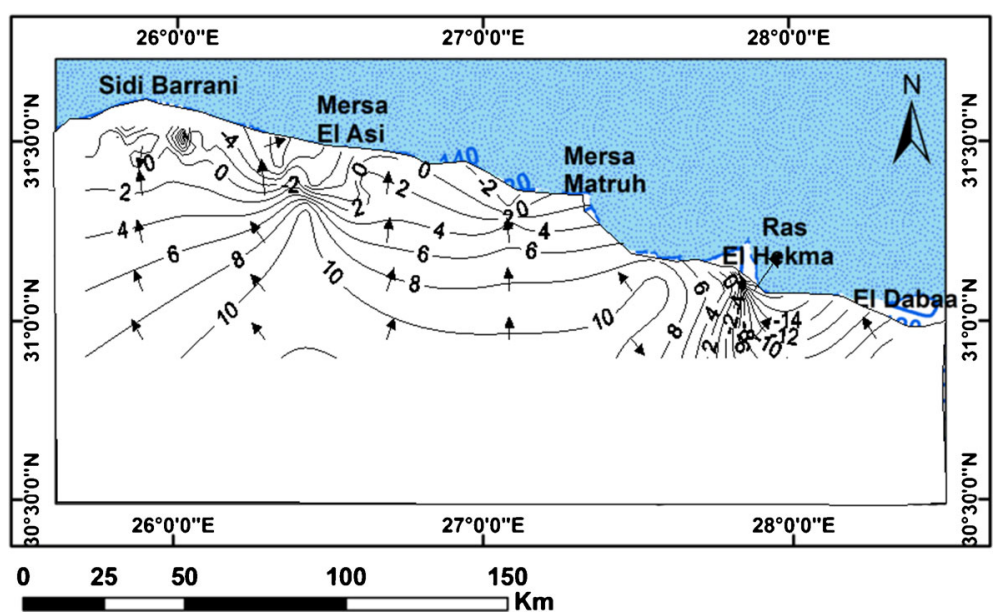

Figure 7. Water table map in the Miocene aquifer.

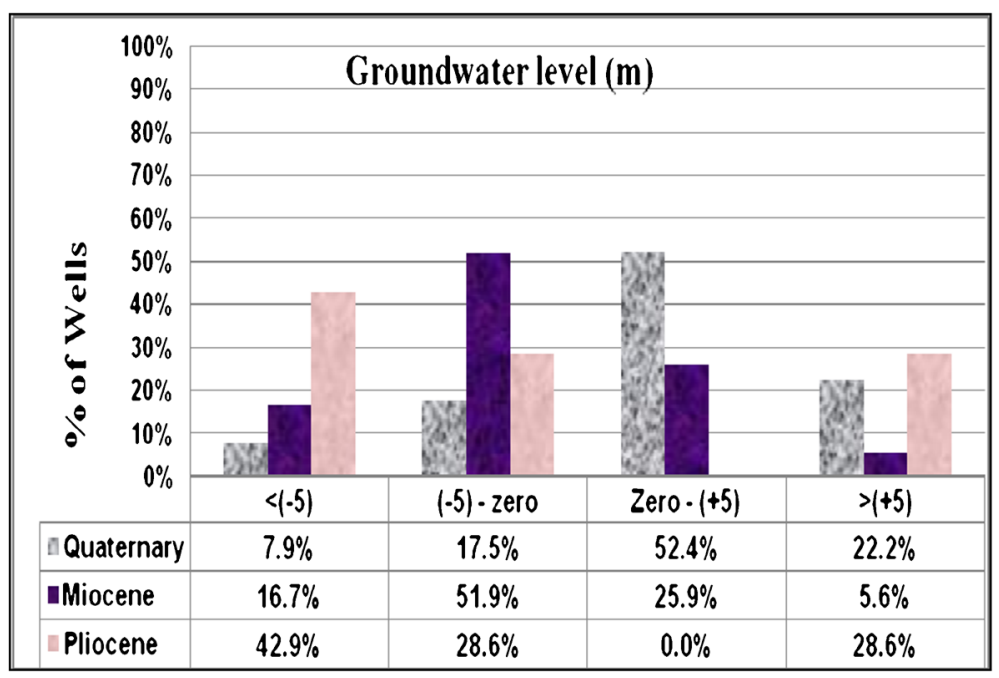

Figure 8. Relation between percentage of wells and water level. 


\section{Quaternary aquifer}

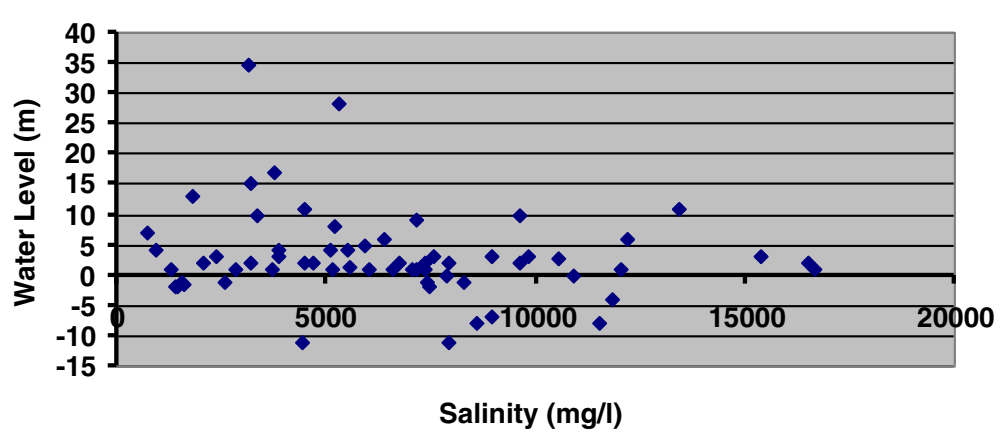

Figure 9. Relation between the water level and groundwater salinity in the Quaternary aquifer.

\section{Miocene aquifer}

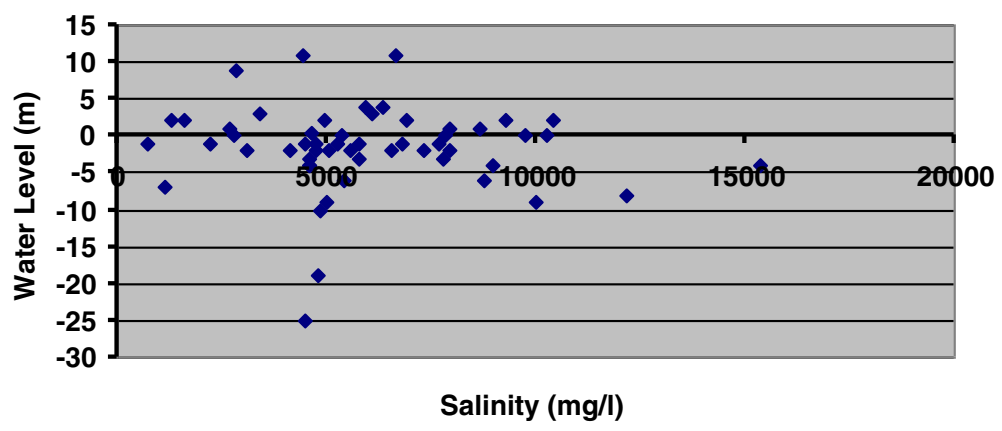

Figure 10. Relation between the water level and groundwater salinity in the Miocene aquifer.

illustrated in figures 11 and 12, where the following are noticed:

- In the Quaternary aquifer, majority of wells $(62 \%)$ have salinities ranging between $<5000$ $\mathrm{mg} / \mathrm{l}$ and $>10000 \mathrm{mg} / \mathrm{l}$ regardless of the actual drilled depth below sea level ranging from zero to $-10 \mathrm{~m}$. About $50 \%$ of them have a salinity category between 5000 and 10000 mg. Actually, the relationship between the groundwater salinity and drilled depth below sea level is ill defined.

- In the Miocene aquifer, about $43 \%$ of the samples are within the range of $1000-5000 \mathrm{mg} / \mathrm{l}$ regardless of the actual drilled depth, which ranges between -30 and $-10 \mathrm{~m}$ below sea level. This also is another indication that there is no trend governing the relationship between drilled depth and groundwater salinity.

\subsection{Estimated optimum yield of brackish groundwater}

To estimate the maximum discharge, which can be taken from the aquifer, for brackish water $(<5000 \mathrm{mg} / \mathrm{l})$, we assume that the safe distance between wells to avoid well interference (cone of depression) is $500 \mathrm{~m}$, i.e., 9 wells $/ \mathrm{km}^{2}$. Such an assumption is based on the following equation to calculate the transmissivity $(T)$ (Brown et al. 1972)

$$
T=\frac{Q}{2 \pi S w} \ln \left(\frac{r e}{r w}\right)
$$

where $Q$ is the well discharge $\left(\mathrm{m}^{3} /\right.$ day $), S w$ is the drawdown in a pumped well $(\mathrm{m}), r w$ is the radius of well $(\mathrm{m})$ and re is the radius of influence $(\mathrm{m})$.

The aquifer test data in the study area indicate that the transmissivity $(T)$ ranges between 25 and $40 \mathrm{~m}^{2}$ /day for the fractured Miocene and from 120 to $180 \mathrm{~m}^{2}$ /day for Oolitic limestone. However, for conditions commonly encountered in unconfined aquifers, radius of influence $(r e)$ is generally about $300 \mathrm{~m}$ (Hamill and Bell 1986). The average well discharge was measured in the field as 10 $\mathrm{m}^{3} / \mathrm{hr}$ for the Quaternary aquifer (porous media) and $5 \mathrm{~m}^{3} / \mathrm{hr}$ for the Middle Miocene (fractured media). The maximum discharge from aquifers for brackish groundwater, according to the iso-salinity maps (figures 4 and 5) was estimated as follows:

- The maximum discharge which can be taken from the Quaternary aquifer, for salinity 1000$5000 \mathrm{mg} / \mathrm{l}$ is $425,000 \mathrm{~m}^{3} /$ day $\left(52,200 \mathrm{~m}^{3} /\right.$ day 


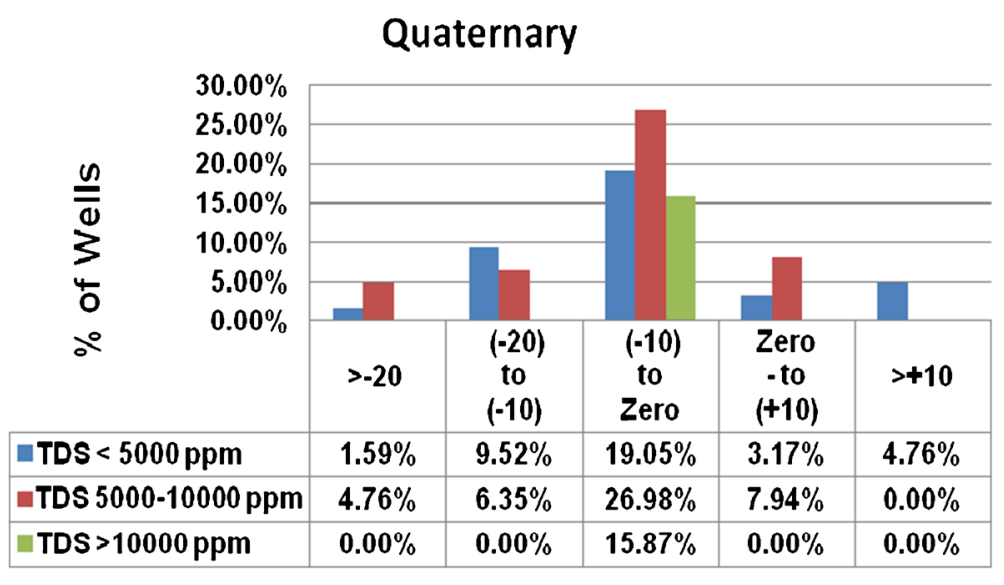

Drilled Depth below Sea Level $(\mathrm{m})$

Figure 11. Percentage of wells and corresponding drilled depth below sea level for different salinity in the Quaternary aquifer.

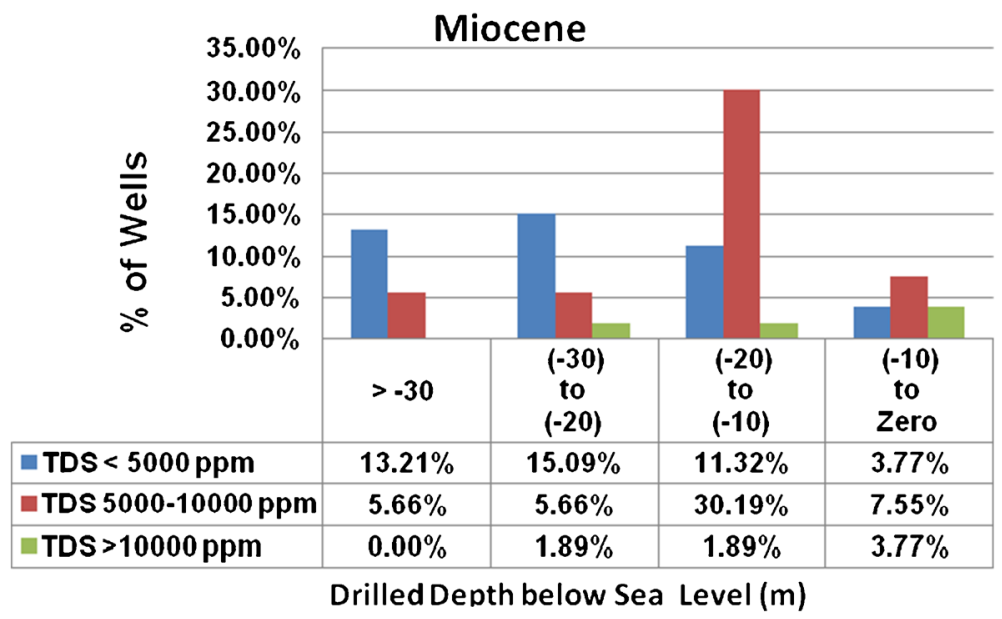

Figure 12. Percentage of wells and corresponding drilled depth below sea level for different salinity in the Miocene aquifer.

in Sidi Barani area and $372,600 \mathrm{~m}^{3} /$ day in Matrouh-El Dabaa area).

- In the Miocene aquifer, the maximum discharge for salinity $1000-5000 \mathrm{mg} / \mathrm{l}$ is $135,000 \mathrm{~m}^{3} /$ day (in the area of Sidi Barani).

- Groundwater having more than $5000 \mathrm{mg} / \mathrm{l}$ should be excluded as a supplement source for irrigation, since it actually harms the soil, especially the fragile soil dominating the Middle Miocene Plateau.

\section{Conclusion}

In the study area, the absolute groundwater level is slightly positive (above the mean sea level) for the Quaternary and Pliocene aquifers, while it is negative, i.e., below sea level, for the Middle Miocene aquifer. This may indicate that both aquifers in the area are probably hydraulically connected, or that each of them has its own factors influencing the contained groundwater salinity.

The area embraced between Mersa Matrouh and Mersa El Asi in the west is structurally affected by the high land, bounding it from east and west, namely Ras Alam El Roum and Abu Laho causing the surface water divide in this specific area to be shifted northward. This leads to a reduction of the width of the coastal plain in this particular area $(25 \mathrm{~km})$ and consequently to a high degree of flood hazard in the existing Wadis, e.g., Wadis El Garawla, El Ramla, Umm Ashtan and Madwar.

The Pleistocene Oolitic limestone aquifer in this particular area attains the highest category of groundwater salinity $(5000-10000 \mathrm{mg} / \mathrm{l})$, while to both west and east directions of this area, the groundwater salinity gets lower and lower.

In general, the Oolitic limestone aquifer in the whole study area has the highest ability to directly recharge from the local rainfall, due to the high permeability of its building material. Unfortunately, 
this aquifer is directly affected by sea water intrusion due to the direct connection between such deposits and the Mediterranean Sea. These conditions affect the groundwater salinity seriously in this particular aquifer.

The Middle Miocene aquifer (fractured limestone) shows a different manner, where in the area lying directly to the east of Sidi Barrani exhibits the lowest category of groundwater salinity (1000$5000 \mathrm{mg} / \mathrm{l}$ ) among the whole investigated area, bearing in mind that the coastal plain in this area (80 km width) is the widest among the whole study area. Naturally, the ability to directly recharge of the Middle Miocene aquifer by local rainfall is expected to be much less than that of the Quaternary aquifer, unless a favourable geologic structure may help in this process. However, the area to the east of Sidi Barrani is highly dissected by long, deep and wide Wadis (e.g., Wasi Mahgin, El Sanab, El Tawila and El Shebity).

Worth mentioning, the relationship between the groundwater salinity and the absolute water level with respect to the mean sea level was found illdefined in the present work. The same conclusion is also applied for the well drilling depth below sea level, in both aquifers, where no considerable changes in water salinity due to those variables were seen.

In conclusion, the groundwater salinity in the study area is highly influenced by different factors, among them the most effective are the geologic structure, ability to recharge by direct rainfall and runoff, and by sea water intrusion especially if the aquifer strata are directly connected with the sea water.

In order to get brackish water with salinities $<5000 \mathrm{mg} / \mathrm{l}$, one can recommend that the promising area for well drilling in the Miocene aquifer is the area that lies in the west of Mersa El Asi (between El Negila and Sidi Barani), while for the Quaternary aquifer two subareas are recommended for well drilling namely between Mersa El Asi and Mersa Matrouh and East El Dabaa.

\section{References}

Brown R H, Konoplyantsev A A, Ineson J and Kovalesky V S 1972 Groundwater Studies - An International Guide for Research and Practice; UNESCO, Paris.

Conoco 1989 Geological map of Egypt 1:500000.

EMA 1950-2000 Egyptian Meteorological Authority, www. nwp.gov.eg/.

Hamill L and Bell F G 1986 Groundwater Resource Development; Cambridge University, London, pp. 214215.

Saleh E 2000 Hydrogeological, geomorphological and geoenvironmental implications for future sustainable development of the northwestern coastal zone of Egypt; Ph.D. Thesis, Faculty of Science, Mansoura University.

Zaki M H 2000 Assessment of surface water runoff in Mersa Matruh Area, northwestern coastal zone, A.R.E.; Ph.D. Thesis, Faculty of Science, Alexandria University, Alexandria, Egypt, 166p. 